BOGUSŁAW ŚLIWERSKI

Akademia Pedagogiki Specjalnej

im. Marii Grzegorzewskiej w Warszawie

\title{
Z ŻALEM ŻEGNAMY
}

1) $\mathrm{W}$ dn. 23 grudnia 2017 r. odszedł od nas na wieczną wartę prof. zw. dr hab. Wladysław Piotr Zaczyński (ur. 3.05.1930 w Poznaniu; zm. 23.12.2017 w Warszawie), pedagog, humanista, emerytowany profesor Wydziału Pedagogicznego Uniwersytetu Warszawskiego. Kierował tam Katedrą Technologii Kształcenia. Po przejściu na emeryturę pracował jeszcze w szkolnictwie niepublicznym w Mazowieckiej Wyższej Szkole Humanistyczno-Pedagogicznej w Łowiczu oraz Górnośląskiej Wyższej Szkole Pedagogicznej im. Kardynała Augusta Hlonda w Mysłowicach. Był członkiem Komitetu Nauk Pedagogicznych PAN. Kariera naukowa Profesora nie była usłana różami, gdyż był niepokornym dydaktykiem ogólnym humanistycznego nurtu, przeciwstawnego dydaktyce neobehawioralnej czy podporządkowanej radzieckiej teorii kształcenia na bazie doktryny marksistowsko-leninowskiej.

Studia pedagogiczne ukończył w 1954 r., zaś tytuł naukowy profesora otrzymał w 1990 r. Wypromował 5 doktorów nauk humanistycznych w dyscyplinie pedagogika. Recenzował dysertacje doktorskie i habilitacyjne, a także dla wydawnictw - monografie naukowe oraz artykuły w czasopismach pedagogicznych. W ostatnich latach włączał się do debat naukowych z zakresu teorii i metodyk kształcenia oraz publikował artykuły w czasopismach popularnonaukowych. Zawsze był oddany nauczycielom, troszcząc się o ich profesjonalizm. Jego rozprawy cieszyły się ogromną popularnością i były wielokrotnie wznawiane. Studenci pedagogiki, ale także dokształcający się nauczyciele bardzo cenili sobie książkę pt. Praca badawcza nauczyciela, bowiem potrafił w niej pisać o sprawach fundamentalnych z metodologicznego punktu widzenia językiem niezwykle przystępnym. To jest wielka sztuka umieć tak pisać, by kanon wiedzy naukowej stał się dla jej odbiorców zrozumiały i tym samym inspirujący do doskonalenia własnej praktyki nauczycielskiej czy/i badawczej. 
Profesor W.P. Zaczyński był z jednej strony afirmatorem teorii wielostronnego nauczania Wincentego Okonia, ale nadał jej spersonalizowany i odschematyzowany wymiar. Uważał, że dydaktycy ogólni, teoretycy kształcenia powinni na nowo odczytać typologię metod i środków kształcenia, (...) gdyz dawny podziat oparty na kryterium angażowanego przez dany sposób receptora utracit spójność z cała teoretyczną resztą dydaktyki ogólnej (Uczenie się przez przeżywanie, 1990, s. 158).

Zaczyński upominał się o uwzględnianie w procesie kształcenia przeżywania przez uczniów wartości, animowania takich sytuacji dydaktycznych, w których będą pobudzane emocje, zaś treści kształcenia będą bogate aksjologicznie. Jak pisał, uczeń musi mieć co przeżywać, bo dzięki kontekstowi emocjonalnemu będzie kojarzyć treści poznawcze z przeżyciami, racje z emocjami. Tak pozyskiwana wiedza będzie trwalsza i bardziej funkcjonalna. Wiedza, przedmiot głównej troski nauczyciela dydaktyka, jest obiektywna wartościa, ale musi się też niq stać dla uczniów. Ale po to, aby stała się również dla uczniów wartościa przez nich samych ceniona musi, jak uczy historia, być odpowiednio wyeksponowana. (Uczenie się przez przeżywanie, 1990, s. 161).

Jak przystało na profesora w pełnym tego słowa znaczeniu, znakomicie pisał recenzje książek naukowych nie tylko z pedagogiki, ale z szeroko pojmowanej humanistyki. Można odczytać z ich treści, jak bardzo chciał przez ich osobiste odczytanie zaznaczyć swój stosunek do ponowoczesnego świata, w którym nie z wszystkim się zgadzał, nie wszystko cenił i akceptował. To także jest wielką sztuką tak pisać o cudzych książkach, by w wyniku własnej recepcji nadać im szczególny wymiar.

Kilka lat temu opublikował w tygodniku katolickim „Niedziela” piękną w treści recenzję dwóch tomów pod wspólnym hasłem: „Ludzie niezwykli” - tomu pierwszego - pióra Alicji Dybkowskiej pt. Zygmunt August oraz tomu drugiego Małgorzaty Kośki pt. Adam Tytus Działyński i Karol Marcinkowski, bowiem dostrzegł w nich niezwykle istotne przesłanie: (...) odpowiadają one na dostrzeżone potrzeby wspótczesnego wychowania, więcej, daja także dowód adekwatnego odczytania „znaków czasu”. Czasy, w których przypadto nam żyć, to okres wyjątkowo złożonej rzeczywistości, w której nietrudno o zagubienie i bezradność. Źródtem niepokoju zdaje się być przede wszystkim ,obowiazywanie” dziś już politycznych i przeniesionych do wychowania haset: pluralizm i tolerancja. Postulowanemu, niemalże prawem stanowionemu, pluralizmowi wartości przydaje się niemal nieograniczona otwartość, a więc $i$-jak to stusznie zauważyt w opublikowanym przed laty artykule na tamach Przegladu Powszechnego bp Karl Lehmann - niepewność. Tak pojmowany pluralizm stat się w istocie źródtem aksjologicznego chaosu, w którym zagubiono kryteria odróżniania dobra od zła, piękna od brzydoty, tego, co godziwe, od tego, co godziwe nie jest, tego, co madre, od tego, 
co na miano mądrości nie zastuguje, a w naukach o wychowaniu, czyli w pedagogice, zagubiono w ogóle prawdę rozumiana zwyczajnie, jako pewność poznania.

Niepewność jest stanem ogarniajacym nas wszystkich, a więc nauczycieli $i$ wychowawców, od których żąda się akceptacji, $w$ imię otwartości na pluralizm i tolerancję-wszystkich współwystępujących, często z sobą sprzecznych, koncepcji pedagogicznych. A pytanie o to, w stosunku do której z pedagogik jest dana koncepcja alternatywna, przestaje być pytaniem merytorycznym, a stać się może - w opinii miłośników alternatyw - nietaktem. Wiemy z kolei, że człowiek źle toleruje chaos i niejako w sposób naturalny poszukuje jego przeciwieństwa, czyli ładu, który jest przecież źródłem pewności i spokoju. Potrzebę ładu odczuwamy wszyscy $i$ z pewnościa jest ona także dana wychowawcom i nauczycielom. Źródłem poszukiwanego ładu dla nas wszystkich jest świadomość własnego miejsca w strukturach pielęgnowanych od pokoleń wartości, mocno utwierdzonych przez historie narodu.

Zacytowałem większy fragment z tej recenzji, by pokazać, jak bardzo Profesor troszczył się o pedagogikę zrównoważonego rozwoju. Nie był przeciwnikiem alternatyw w edukacji, ale takich ich iluzji, fasad czy podróbek, które tworzyły niepewność, chaos skutkując błędami dydaktycznymi i wychowawczymi także w naszym szkolnictwie. Profesor Władysław Piotr Zaczyński obchodził osiemdziesiąte urodziny siedem lat temu w gronie uczonych Uniwersytetu Pedagogicznego im. Komisji Edukacji Narodowej w Krakowie w dn. 24 września 2010 r., mimo że to Wydziałowi Pedagogicznemu poświęcił wszystkie lata swojego życia i twórczości naukowo-dydaktycznej. Tak to już bywa z emerytowanymi profesorami, że bliżsi stają się swoim uczniom, wychowankom, wypromowanym doktorom czy doktorom habilitowanym, aniżeli nowej generacji akademickiej we własnej Alma Mater.

W czasie zorganizowanemu przezjednego z naukowych partnerów - prof. Janusza Morbitzera na Wydziale Pedagogicznym UP w Krakowie 20. Sympozjum prof. Władysław P. Zaczyński mówił o tym, z czym nadal nie mogą poradzić sobie młodzi naukowcy, a mianowicie o postępie i nowoczesności w dydaktyce ogólnej. Jak wówczas zaznaczył w referacie plenarnym: ,nowoczesność ” $i$, postęp”, czesto sa ze sobą kojarzone, ale nie zawsze ida w parze. Wysoki poziom nasycenia technologiami procesu dydaktycznego nie zawsze daje postep. (...) aktualny etap , informatyczny” traktowany jest bardzo czesto jako osobny. Błędem jest nieczynienie użytku z doświadczeń okresu poprzedniego. Grozi nam nowa postać werbalizmu technicznego. Poznawanie lasu wymaga pójścia do lasu, a nie ogladania na filmie. Konieczne jest zatem odnajdywanie wspólnoty myśli przez wszystkie generacje uczonych.

Publikacje zmarłego Profesora stanowią inspirację do dalszych badań naukowych i konstruowania eksperymentów pedagogicznych: 
Zaczyński W. Praca Badawcza Nauczyciela, Wyd. Szkolne i Pedagogiczne, Warszawa, 2002.

Zaczyński W. Statystyka w pracy badawczej nauczyciela, Wyd. ŻAK, Warszawa, 1997.

Zaczyński W. Poradnik autora prac seminaryjnych, dyplomowych i magisterskich, Wyd. ŻAK, Warszawa, 1995.

Zaczyński W. Uczenie się przez przeżywanie: rzecz o teorii wielostronnego kształcenia, Wyd. ŻAK, Warszawa, 1990.

Zaczyński W. Metodologiczna tożsamość dydaktyki, Wyd. Wydawnictwo Szkolne i Pedagogiczne, Warszawa, 1988.

Zaczyński W. Praca badawcza nauczyciela, Wyd. Szkolne i Pedagogiczne, Warszawa, 1968.

Zaczyński W. Rozwój metody eksperymentalnej i jej zastosowanie w dydaktyce, Wyd. PWN, Warszawa, 1967.

2) W dniu 30 września 2018 roku odeszła dr Halina Rotkiewicz - Sekretarz Generalny Polskiego Towarzystwa Pedagogicznego, Członek Honorowy i Członek Rady Naukowej Polskiego Towarzystwa Pedagogicznego, a przez ostatnie lata także wiceprzewodnicząca Oddziału Warszawskiego PTP. Od początku swojej akademickiej służby była zatrudniona na Wydziale Pedagogicznym Uniwersytetu Warszawskiego. Ostatnio pracowała na stanowisku starszego wykładowcy w Zakładzie Humanistycznych Podstaw Pedagogiki, Pracowni Pedagogiki Ogólnej i Filozofii Edukacji. Przed kilku laty, dodatkowo pracowała na stanowisku adiunkta w Wyższej Szkole Pedagogicznej Związku Nauczy cielstwa Polskiego w Warszawie. Przez wiele lat przedmiotem jej fascynacji badawczej była właśnie filozofia edukacji oraz filozoficzne problemy cywilizacji technologicznej. Bardziej zajęta była kształceniem innych, niż troską o własny awans naukowy. Znakomicie realizowała się w roli przewodniczącej Oddziału Warszawskiego PTP systematycznie organizując otwarte spotkania, wykłady, debaty czy dyskusje na temat przemian w światowej myśli pedagogicznej.

Należała do tej grupy nauczycieli akademickich, którzy z racji pedagogicznych kwalifikacji chcą być jak najbliżej praktyki, tych, którzy stają się lub już są pedagogami w szerokim tego słowa znaczeniu. Właśnie dlatego z odpowiedzialnością i troską zajmowała się sprawami organizacyjnymi i funkcją oświatową Polskiego Towarzystwa Pedagogicznego. Tu angażowała się w przygotowanie kolejnych posiedzeń jego władz, prezydium, plenum, ale i dawała wyraz własnym analizom i przemyśleniom w odrębnych publikacjach. Ostatnią taką było jej sprawozdanie z Walnego Zjazdu Delegatów i Jubileuszu 35-lecia PTP. 
Jako adiunkt, a później wykładowca Wydziału Pedagogicznego UW pani dr H. Rotkiewicz była zaangażowanym świadkiem i biografistą dokonań mistrzów polskiej pedagogiki dokumentując je m.in. w swoich wywiadach z nestorami naszej dyscypliny. Tylko ktoś tak profesjonalnie wykształcony mógł przeprowadzić niebanalny wywiad z prof. Stefanem Wołoszynem (zob. Wydział Pedagogiczny Uniwersytetu Warszawskiego. Jubileusz pięćdziesięciolecia, red. J. Kamińska (Warszawa 2004, ss. 119-125). Przeprowadziła dwie debaty z biografistyki pedagogicznej poświęcone wybitnym polskim humanistom: Sergiuszowi Hessenowi i Florianowi Znanieckiemu. Pod jej redakcją ukazały się dwa, jakże znaczące dla recepcji ich dzieł tomy: Filozofia wychowania Sergiusza Hessena (wstęp i red. naukowa), Warszawa 1997; Florian Znaniecki.Myśl społeczna a wychowanie. Inspiracje dla współczesności (wstęp i red. naukowa), Warszawa 2001. To właśnie we wstępie do rozprawy poświęconej Hessenowi podzieliła się także swoim sposobem postrzegania istoty wychowania pisząc m.in.: Filozofia wychowania Sergiusza Hessena ukazuje jasno, że człowiek nigdzie indziej nie znajdzie źródła sity $i$ istoty własnego człowieczeństwa jak tylko w sobie: sobie zwróconym ku kulturze $i$ innym ludziom. Wychowanie zatem powinno otwierać horyzonty wolności i czynić czlowieka odpowiedzialnym. Czyż nie tego nam trzeba $w$ czasie „,demontażu jaźni moralnej?" (s. 12)

3) W dn. 5. 10. 2018 r. - zmarł prof. Uniwersytetu Humanistyczno-Przyrodniczego im. Jana Długosza w Częstochowie - dr hab. Bogdan Snoch (ur. 1933) pedagog, historyk oświaty i wychowania, który od kilkunastu lat przebywał już na emeryturze. Zmarł 5 października 2018 r. w wieku 85 lat. Częstochowianie znają śp. profesora z jego publikacji. Był on bowiem autorem Małej encyklopedii Częstochowy, Legend $i$ baśni znad Warty obejmujących teren całego województwa częstochowskiego, a nie ograniczając się - jak wskazuje na to tytuł książki-jedynie do terenów leżących nad górną Wartą. Wydał tez zbiór esejów historycznych pt. Tragedia Piotra Włostowica oraz Powrót do piastowskich granic.

W ostatnich latach szczególnie interesowała Profesora AJD leksykografia. Wspólnie z Romanem Tusiewiczem napisał i opublikował Szkolny stownik historii Polski 1918-1989 rok, zaś z Jerzym Skowronkiem wydał: Szkolny stownik historii Polski. Czasy porozbiorowe 1795-1918. Tom II. Jest też autorem skryptów, podręczników i pomocy dydaktycznych w kształceniu historycznym, w tym m.in. leksykonu Terminy i pojęcia historyczne. Pasja historyka, badacza regionalnych wydarzeń, postaci i procesów historycznych wzbudzała duże zainteresowanie wśród młodzieży akademickiej. Przez wiele lat Profesor pracował w Instytucie Pedagogiki Wyższej Szkoły Lingwistycznej w Częstochowie. Dla historii wychowania ważna jest rozprawa habilitacyjna B. Snocha pt. Odbudowa szkolnictwa 
w woj. śląsko-dąbrowskim w latach 1945-1950, która była w listopadzie 1995 r. podstawą przewodu habilitacyjnego na Wydziale Filologiczno-Historycznym Uniwersytetu Opolskiego.

4) zm. 29.10.2018 r. dr hab. Robert Kwaśnica - profesor, współzałożyciel, rektor, prezydent Dolnośląskiej Szkoły Wyższej we Wrocławiu, pedagog.

W 1972 ukończył studia pedagogiczne na Wydziale Filozoficzno-Historycznym Uniwersytetu Wrocławskiego, gdzie podjął po nich pracę w Instytucie Pedagogiki. W latach 1979-1981 przeniósł się do Instytutu Nauk Społecznych Politechniki Wrocławskiej, gdzie w latach 1980-1981 był zastępcą dyrektora Ośrodka Badań Procesu Dydaktycznego i Wychowawczego. W 1980 obronił na Uniwersytecie Wrocławskim rozprawę doktorską pt. Struktura sytuacji problemowej a funkcjonalność wiedzy ucznia. W latach 1982-1997 powrócił do Instytutu Pedagogiki Uniwersytetu Wrocławskiego, zaś w 1991 r. uzyskał stopień doktora habilitowanego nauk humanistycznych w dyscyplinie pedagogika na podstawie rozprawy zatytułowanej Dwie racjonalności. Od filozofii sensu ku pedagogice ogólnej. W latach 1992-1997 kierował Zakładem Pedagogiki Ogólnej w Instytucie Pedagogiki, w 1993 był prodziekanem Wydziału Nauk Historycznych i Pedagogicznych UWr. W latach 1993-1998 wykładał także w Wyższej Szkole Pedagogicznej w Zielonej Górze.

Po uzyskaniu habilitacji odłożył własne aspiracje naukowe na bliżej nieokreśloną przyszłość, by zatroszczyć się przede wszystkim o innych, a dzięki nim o inną pedagogikę, o inną kulturę naukową, dydaktyczną i edukacyjną. Powołał do życia przy TWP we Wrocławiu Dolnośląską Szkołę Wyższą zatrudniając w niej młodych uczonych, gdzie ,doprowadził” ich do doktoratu, habilitacji i tytułu profesora. Stworzył nie tylko uczelnię, ale wyjątkową kulturę akademicką o międzynarodowym statusie, tworzącą zupełnie nową przestrzeń dla kongresów na światowym, a nie jedynie krajowym czy jedynie bilateralnym poziomie. Tu zaistniało dzięki prof. Mieczysławowi Malewskiemu jedno z najważniejszych polskich czasopism pedagogicznych o jakże wymownym, interdyscyplinarnym tytule: „Teraźniejszość-Człowiek-Edukacja”, a stanowiące transgresyjny i transwersalny przekaz idei, wyników badań i naukowych sporów.

Pisał: Głównym zadaniem czasopisma jest animacja dialogu pomiędzy przedstawicielami nauk spolecznych, którzy patrza na procesy oświatowe i instytucje nauczające $z$ różnych perspektyw dyscyplinowych i odmiennych orientacji aksjologicznych. Edukacja dotyka wszystkich, ponieważ będąc istota społeczna, czlowiek jest zarazem istota uczaca się i nauczająca. Rzeczywistość spoleczna w jakiej przyszło nam żyć i pracować, okazała się rzeczywistościa nieprzewidywalną. Dlatego nie rezygnują z prospektywnego myślenia o edukacji, naszą uwa- 
ge pragniemy skupić przede wszystkim na teraźniejszości. Mglista i nieprzejrzysta teraźniejszość, która stała się naszym udziatem, wymaga interpretacji i intelektualnego oswojenia. Zadanie to stawiamy przed autorami i wspótpracownikami kwartalnika.

Robert Kwaśnica stworzył świat możliwej, alternatywnej pedagogiki humanistycznej, która miała tworzyć świat szczęśliwości każdego jej podmiotu, chociaż miał świadomość tego, że nie jest to całkiem możliwe. Były też chwile radości i taksatysfakcji, kiedy został wybrany członkiem Komitetu Nauk Pedagogicznych Polskiej Akademii Nauk, służąc całemu środowisku, a także, gdy otrzymywał za swoją twórczość naukową i osiągnięcia w szkolnictwie niepublicznym nagrody Ministra Edukacji Narodowej oraz gdy został odznaczony przez Prezydenta RP Krzyżem Kawalerskim Orderu Odrodzenia Polski (2011). Zostawił swoje pedagogiczne credo, w ostatnich latach skoncentrowane na modelu własnej szkoły marzeń dla dzieci, skoro w warunkach drapieżnego kapitalizmu, zdrad, hipokryzji, powszechnej nieuczciwości wokół nie było możliwe dopięcie projektu prywatnego uniwersytetu. 